\title{
CD2-Positive Neoplastic Cells Present
}

National Cancer Institute

\section{Source}

National Cancer Institute. CD2-Positive Neoplastic Cells Present. NCI Thesaurus. Code C150563.

An indication that expression of CD2 has been detected in a sample of neoplastic cells. 